\section{Triatomine infestation and vector-borne transmission of Chagas disease in northwest and central Paraná, Brazil}

\author{
Infestação triatomínica e transmissão \\ vetorial da doença de Chagas no noroeste \\ e centro do Paraná, Brasil
}

\author{
Ana Lucia Falavigna-Guilherme 1 \\ Rosângela Santana 2 \\ Gilberto Cezar Pavanelli 4 \\ Elias Seixas Lorosa 4 \\ Silvana Marques de Araújo 1
}

1 Departamento de Análises Clínicas, Universidade Estadual de Maringá, Maringá, Brazil.

2 Departamento de Estatística, Universidade Estadual de Maringá, Maringá, Brazil.

3 Programa de Pós-graduação em Ecologia de Ambientes Aquáticos Continentais, Universidade Estadual de Maringá, Maringá, Brazil. 4 Departamento de Entomologia, Instituto Oswaldo Cruz, Rio de Janeiro, Brazil.

Correspondence A. L. Falavigna-Guilherme Departamento de Análises Clínicas, Universidade Estadual de Maringá. Av. Colombo 5790, Bloco I-90/13, Maringá, PR 87020-900, Brasil. alfguilherme@uem.br

\section{Abstract}

Triatomine infestation, prevalence of $\mathrm{T}$. cruzi antibodies in humans and domestic animals, and variables potentially associated with the presence of triatomines in a rural domiciliary unit (DU) were investigated in nine municipalities and one district of Paraná, Brazil, from June 1996 to February 2000. DUs were defined as all houses and annexes on a given piece of property. Blood samples from human volunteers, dogs, and cats were submitted to indirect immunofluorescence. An epidemiological form was completed for each DU. A logistic model was adopted in order to identify associations. Seven out of nine municipalities were positive for triatomines. T. infestans was not captured, but T. sordida, P. megistus, and R. neglectus were. Different variables were considered decisive for the presence of triatomines across the municipalities: proximity to residual wooded areas, i.e. either scrub forest (capoeira) or islands of residual forest (slightly dense vegetation), longer time of residence, existence of inhabited houses, and past DU infestation. In order to ensure proper continuation of the recommended Chagas disease control program, entomo-epidemiological surveillance measures need to be maintained.

Triatoma; Epidemiologic Factors; Chagas Disease

\section{Introduction}

Over the last thirty years, Chagas disease transmission has declined significantly both in Brazil and in a large part of Latin America as a whole, as a result of vector control through the use of insecticides and improvements in rural housing, living standards, and education 1 . In Brazil, rural exodus in the 1970s and '80s reduced the use of manual labor in rural areas, thereby increasing the number of inhabited houses, which provide ideal shelter for Triatoma infestans Klug, 18342.

In Brazil, the elimination of triatomines from domestic environments does not avoid the persistence of residual foci, particularly in the peridomicile 3 , due to the invasion and colonization of artificial ecotopes by triatomines whose natural habitat is the sylvatic ecotope. Such triatomes include Panstrongylus megistus (Burmeister, 1835), Triatoma sordida (Stal, 1859), Triatoma braziliensis (Neiva, 1911), Rhodnius prolixus (Stal, 1859), and others 4 .

Camargo et al. 5 reported that the state of Paraná, Brazil, had an elevated number of seropositive individuals for Chagas disease, placing it fourth among all Brazilian States in a serological survey to determine Chagas infection. Until 1995, current data were scarce in the literature in relation to secondary triatomine species in Paraná 6,7,8,9. Toledo et al. 10 found that $98.7 \%$ of the triatomines collected in rural areas of 
municipalities in northwest Paraná belonged to the Tr. sordida species. However, Silveira \& Vinhaes 11 did not report any triatomines in this State during an investigation carried out by the National Health Foundation (FUNASA) from 1995 to 1997. Furthermore, Falavigna-Guilherme et al. 12 analyzed the majority of municipalities from the present study and found that uninhabited houses were the most frequently infested ecotopes, followed by chicken coops and inhabited houses.

The lack of current information on Trypanosoma cruzi infection and triatomine behavior in the domiciliary and peridomiciliary environments motivated the present investigation on triatomine infestation, prevalence of T. cruzi antibodies in humans and domestic animals, and variables possibly associated with the frequency of triatomines in such environments in Paraná State.

\section{Material and methods}

\section{Study area}

Fieldwork was carried out in the rural areas of nine municipalities in Paraná that are located mainly in the northwestern region of the State. The northwest Paraná meso-region is situated between $52^{\circ} 20^{\prime}$ and 5250' longitude West and $23^{\circ} 20^{\prime}$ and $23^{\circ} 60^{\prime}$ latitude South. The region is part of the geomorphological unit called the Paraná Basin Central Plateau 13, which is part of the Third Paraná or Sandstone-Basaltic Plateau. The terrain consists of low, flat-topped plateaus with convex slopes that reach altitudes of 250 to $600 \mathrm{~m}$. The climate is classified as warm, super-humid tropical 14 . Average annual rainfall is $1,700 \mathrm{~mm}$. In the dry winter season, average temperatures are below $18^{\circ} \mathrm{C}$, while the average yearly low is $16^{\circ} \mathrm{C}$ and the average annual highs range from 26 to $28^{\circ} \mathrm{C} 15$. The overall annual temperature is $21.9^{\circ} \mathrm{C}$.

Nearly $95 \%$ of the original vegetation in the northwestern region of the State, consisting of latifoliate subtropical forest, was destroyed to make way for cropland 16. The region's current economy is dominated by production from small and medium-sized farms. The farming industry consists mainly of feedlot production and crops including soybeans, corn, sugarcane, manioc, wheat, and grapes 15 . The rural exodus from northwest Paraná has been intense since the 1970s 16. Many dwellings from earlier decades that had been linked to coffee growing were torn down, while most of the remaining structures were abandoned. Today, approxi- mately $90 \%$ of the existing houses are built of wood with ceramic tile roofs and have electricity.

In the north-central Paraná meso-region (or second plateau), only the municipality of Cândido de Abreu was studied. Despite vast wastelands, the region has small areas of mixed vegetation including Brazilian pine and broadleafed tropical woodlands 13. The municipality of Cândido de Abreu has an altitude of $600 \mathrm{~m}$ and is situated at $51^{\circ} 19^{\prime}$ longitude West and 24³6' latitude South. The climate is mesothermal, humid, and subtropical with hot summers, concentrated rainfall, average temperatures over $22^{\circ} \mathrm{C}$ in the hottest month and 26 to $27^{\circ} \mathrm{C}$ average annual highs 14 . Freezing temperatures in the winter are infrequent. Minimum temperatures are around $12.7^{\circ} \mathrm{C}$, with 14 and $15^{\circ} \mathrm{C}$ as the average annual lows. There is no well-defined dry season 15 . Economic production is centered on range-fed livestock production. However, there is also crop cultivation, mainly beans, tobacco, corn, potatoes, and soybeans ${ }^{13}$. The municipality has extensive poverty, and mud-and-wattle houses are not uncommon in the rural area 13 . Its territory is approximately equivalent to the total of the other municipalities studied here (Figure 1).

Due to intense deforestation in the State of Paraná, what remains is a predominance of primitive, seasonal, latifoliate forest that appears in the considerably modified form of thinly-spread forest and scrub, characterized by open spaces with only sparse vegetation, punctuated by small trees and shrubs/bushes that are highly exposed to solar radiation. This description agrees with that of Forattini 17, who portrays Paraná as an originally umbrageous area, currently reduced to mainly open spaces due to anthropic action and presenting an ugly landscape dotted with islands of residual vegetation.

\section{Municipalities studied}

Figure 1 shows the study area of eight municipalities and one district in northwest Paraná, and one municipality located in the central part of the State.

The selection of municipalities was based on work by FUNASA, guided by frequent findings of triatomines by inhabitants of these municipalities and by entomo-epidemiological data from each municipality obtained in the 1980s, classifying them as levels I, II, or III in terms of priority. According to FUNASA technical standards 18 , priority I municipalities are those where it is still possible to find Tr. infestans (the main Chagas disease vector) in the 

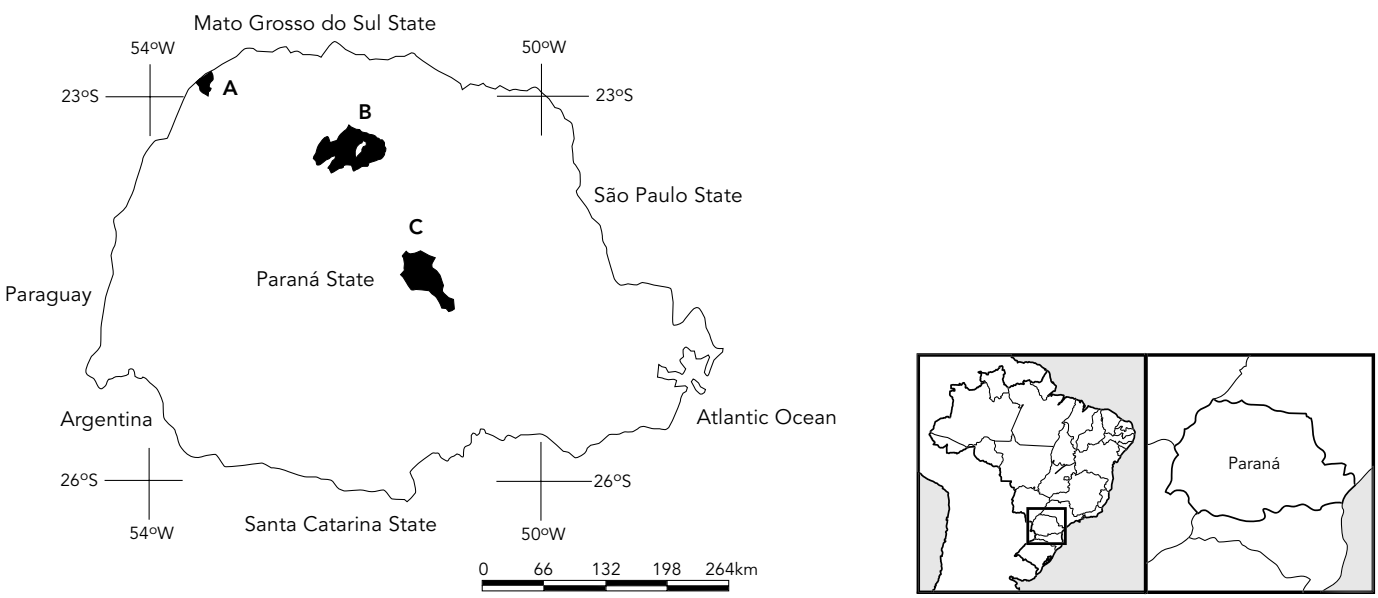
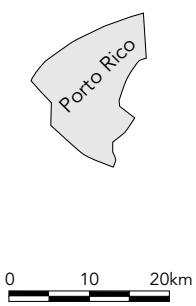

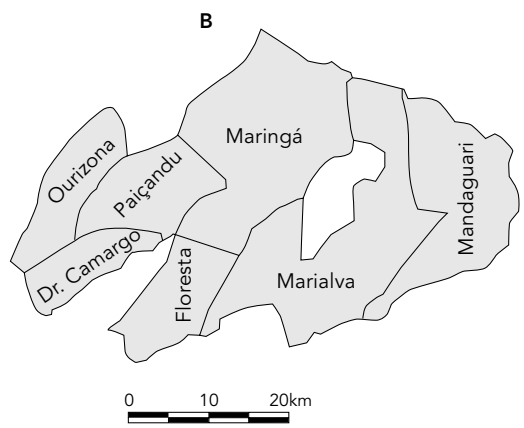

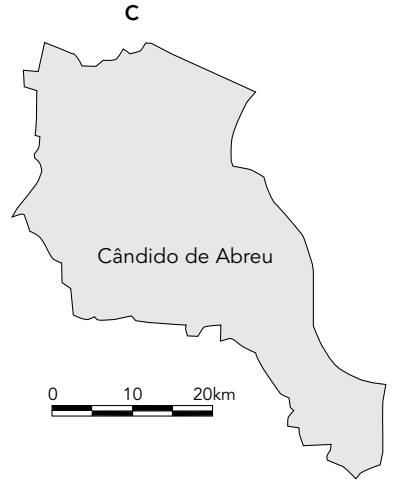

domiciliary or peridomiciliary environments. In these areas, research is conducted annually to identify triatomines. Priority II municipalities are those where FUNASA has verified the colonization of an inhabited domicile within the last three years, or where reports have been made of the presence of secondary species such as Tr. sordida and P. megistus. This classification requires that farms within the municipalities be surveyed every two years for triatomines. Priority III municipalities are those where FUNASA has identified colonization by Tr. sordida and P. megistus in peridomiciliary annexes in the previous five years, and require triatomine surveys every three years.

The municipalities of Floresta, Mandaguari, Ourizona, and Maringá, including the rural area of the Floriano district, are classified by FUNASA-Paraná as "priority II". The munici- palities of Paiçandu, Dr. Camargo, and Marialva are considered "priority III", while Cândido de Abreu is "priority I". The Municipality of Porto Rico has not been classified by FUNASA.

In these municipalities, work by FUNASA was conducted four days a week. To obtain the present data, the team from the State University of Maringá (UEM) accompanied FUNASA one day a week. This procedure meant that data collection had to occur at homogeneously distributed locations in each municipality at different points.

\section{Procedures}

The study was conducted according to the FUNASA activity timeline for entomological surveillance or based on reports of infestation submitted to FUNASA. Triatomines and epi- 
demiological information were collected weekly by teams from UEM and FUNASA from June 1996 to February 2000.

\section{Entomological inspection}

The search for triatomines in houses and annexes was carried out by a team of six workers from FUNASA and three from UEM. A "domiciliary unit" (DU) was defined as all the houses plus annexes (chicken coops, pigsties, barns, wood sheds, stables, etc.) at each of the rural properties visited (cabins, cottages, farms). An uninhabited DU was defined as a DU with no residents and was considered as a whole, without distinction between intradomiciliary and peridomiciliary environments.

Triatomines were captured manually from external and internal walls, roofs, furniture, mattresses, and other objects within the domiciles. The capture methodology could not be classified in "man/hours" or "dislodging insecticide employed" since the entire DU was searched, regardless of the time spent on it. The finding of triatomines signaled the end of the search in a given DU. Similar procedures were adopted for inhabited and uninhabited DUs and were considered positive if nymphs and/or adults were found. Infested DUs were treated by FUNASA with the insecticide cypermethrin (125mg active ingredient $/ \mathrm{m}^{2}$ ).

At least $10.0 \%$ of existing DUs were inspected in municipalities of up to 900 DUs. For municipalities with over 900 DUs, a minimum of $1.0 \%$ was inspected.

\section{Prevalence of $T$. cruzi antibodies in humans}

Blood samples were collected from volunteers who gave informed consent. The samples collected for this work were calculated using the computer program Epi Info version 6.0 considering the rural population of each municipality, a prevalence of $4 \% 5$, and $95 \%$ confidence levels. Samples were collected at all sites. They were deposited on filter paper after finger sticks with sterile, disposable lancets, dried at room temperature, and stored at $-20^{\circ} \mathrm{C}$ until use. All blood samples were submitted to indirect immunofluorescence (IIF) according to Camargo et al. 5, using T. cruzi Biolab antigens and Sigma conjugate. Positive results were later confirmed by IIF in serum derived from a new blood sample collected via venipuncture. Seropositive subjects (titer $\geq 1: 40$ ) were referred to the Health Care and Comprehensive Education Program for Chagas Patients (ACHEI) for the Municipality of Maringá and northwest region of Paraná, a follow-up program for Chagas patients run by UEM 19 .

\section{Prevalence of $T$. cruzi antibodies} in cats and dogs

Priority was given to animals that most frequently entered wooded areas near domiciles. Blood from cats and dogs was collected onto filter paper from a small ear incision. Samples were processed by IIF according to Camargo et al. 5 using specific anti-dog and anti-cat Sigma conjugates and Biolab antigens.

\section{Epidemiological data collection instrument}

The form utilized was based on the model used by Diotaiuti et al. 3. During site visits, one form was completed for each DU, whether inhabited or not. Data included type of dwelling, number of residents, length of residence, presence of annexes and distance from the domicile, presence of animals, distance to closest DU, distance of DU from residual wooded areas in general ("scrub forest" or "islands of residual forest”), and presence of triatomines.

\section{Statistical analysis}

Data from the epidemiological forms, entomological inspection, and serological results were entered into a database using the Statistica Program version 8.0. Since it was binary, a logistic model was adopted to describe the response 20 . The clustered $\mathrm{K}$-averages model was used to categorize the quantitative explanatory variables. Statistical analysis of the information collected from each municipality consisted of describing the characteristics of the DUs, identifying associations, and obtaining a model that would explain the presence of triatomines.

\section{Research Ethics Committee approval}

The study protocol was approved by the UEM Institutional Ethics Committee. All study participants provided informed consent.

\section{Results}

Different localities were investigated in each municipality (841/143) (Table 1), corresponding to $17.0 \%$ of existing sites. Triatomines were found in seven of the nine municipalities analyzed and in the Floriano district (Table 1). Of the captured triatomines, $92.4 \%$ were found in houses and annexes built of wood. 
Investigation of triatomine infestation in domiciliary units (DUs) in rural areas of municipalities in Paraná State, Brazil, from June 1996 to February 2000.

\begin{tabular}{|c|c|c|c|c|c|c|c|c|c|c|c|}
\hline \multirow{3}{*}{$\begin{array}{l}\text { Municipality } \\
\text { or district/ } \\
\text { FUNASApriority } \\
\text { classification }\end{array}$} & \multirow{2}{*}{\multicolumn{2}{|c|}{$\begin{array}{c}\text { Total sites/ } \\
\text { Sites investigated }\end{array}$}} & \multirow{3}{*}{$\begin{array}{l}\text { Period of } \\
\text { investigation }\end{array}$} & \multicolumn{6}{|c|}{ DUs positive for triatomines } & \multirow{2}{*}{\multicolumn{2}{|c|}{$\begin{array}{l}\text { Triatomine specie } \\
\text { Total captured }\end{array}$}} \\
\hline & & & & & nhabite & & Uninhabite & & & & \\
\hline & Number & $\%$ & & Number & $\%$ & Intra* & Peri** & Number & $\%$ & Nympl & Adult \\
\hline \multirow{2}{*}{ Paiçandu /III } & $20 / 18$ & 90.0 & Jun-Jul-Aug/1996, & 22 & 36.7 & 4 & 20 & 9 & 75.0 & \multicolumn{2}{|c|}{ T. sordida } \\
\hline & & & Aug-Oct/1999 & & & & & & & 168 & 57 \\
\hline \multirow[t]{2}{*}{ Dr. Camargo /III } & $24 / 14$ & 58.3 & Aug-Oct/1996 & 10 & 14.3 & 0 & 10 & 2 & 100.0 & \multicolumn{2}{|c|}{ T. sordida } \\
\hline & & & & & & & & & & 77 & 20 \\
\hline \multirow[t]{2}{*}{ Floriano /II } & $19 / 13$ & 68.4 & Oct-Dec/1996 & 6 & 10.2 & 1 & 5 & 1 & 100.0 & \multicolumn{2}{|c|}{ T. sordida } \\
\hline & & & & & & & & & & 47 & 12 \\
\hline \multirow[t]{2}{*}{ Floresta /II } & $24 / 14$ & 58.3 & May-Jul/1997 & 4 & 9.5 & 0 & 4 & 0 & 0.0 & \multicolumn{2}{|c|}{ T. sordida } \\
\hline & & & & & & & & & & 5 & 6 \\
\hline \multirow[t]{2}{*}{ Mandaguari /II } & $114 / 19$ & 16.7 & Apr-May/1999, & 3 & 4.5 & 2 & 1 & 2 & 40.0 & \multicolumn{2}{|c|}{ P. megistus } \\
\hline & & & $\begin{array}{l}\text { Jan-Feb/1998, } \\
\text { Jul-Aug and Dec/1997 }\end{array}$ & & & & & & & 18 & 11 \\
\hline Ourizona /II & $21 / 13$ & 61.9 & Jul-Aug/1998 & 0 & 0.0 & 0 & 0 & 0 & 0.0 & 0 & 0 \\
\hline \multirow[t]{4}{*}{ Marialva /III } & $131 / 7$ & 5.3 & Mar-May/1998 & 2 & 4.4 & 1 & 1 & 0 & 0.0 & \multicolumn{2}{|c|}{ T. sordida } \\
\hline & & & & & & & & & & 25 & 25 \\
\hline & & & & & & & & & & \multicolumn{2}{|c|}{ P. megistus } \\
\hline & & & & & & & & & & 1 & 0 \\
\hline Cândido de & $318 / 4$ & 1.3 & Mar-Apr/1999 & 0 & 0.0 & 0 & 0 & 0 & 0.0 & 0 & 0 \\
\hline \multicolumn{12}{|l|}{ Abreu /I } \\
\hline \multirow[t]{4}{*}{ Maringá /II } & $145 / 30$ & 20.7 & Apr-Aug/1999 & 7 & 13.0 & 2 & 5 & 2 & 40.0 & \multicolumn{2}{|c|}{ T. sordida } \\
\hline & & & & & & & & & & 7 & 3 \\
\hline & & & & & & & & & & \multicolumn{2}{|c|}{ P. megistus } \\
\hline & & & & & & & & & & 22 & 14 \\
\hline \multirow[t]{4}{*}{ Porto Rico } & $25 / 11$ & 44.0 & Dec/1999, & 2 & 6.1 & 2 & 1 & 0 & 0.0 & \multicolumn{2}{|c|}{ P. megistus } \\
\hline & & & Jan-Feb/2000 & & & & & & & 0 & 2 \\
\hline & & & & & & & & & & \multicolumn{2}{|c|}{ R. neglectus } \\
\hline & & & & & & & & & & 0 & 2 \\
\hline Total & $841 / 143$ & 17.0 & & 56 & 11.0 & 12 & 47 & 16 & 27.6 & 370 & 152 \\
\hline
\end{tabular}

* Intradomiciliary environment, ** Peridomiciliary environment, FUNASA: Brazilian National Health Foundation.

More DUs than the number established for the sample selection criterion were investigated (Table 2). Secondary triatomine species were found in $72(12.7 \%)$, including 56 (11.1\%) inhabited and 16 (27.6\%) uninhabited (Table 1). The Municipality of Paiçandu was the most infested, with $36.7 \%$ of inhabited DUs and $75.0 \%$ of uninhabited DUs testing positive (Table 1). No triatomines were found in the Cândido de Abreu or Ourizona municipalities (Table 1).

As shown in Table 1, 522 samples of the $T r$. sordida, $P$. megistus, and $R$. neglectus species were collected, of which 370 were nymphs (70.9\%) and $152(29.1 \%)$ adults. The majority of the specimens were $T r$. sordida, which represented $86.6 \%$ (329 nymphs and 123 adults) of all the triatomines collected, mainly in the peridomicile. P. megistus (41 nymphs and 27 adults) was the second most common species (13.0\%). Only two specimens of adult $R$. neglectus were identified.

Triatomines captured in the intradomicile of inhabited DUs were mainly adults (nine $T r$. sordida, five $P$. megistus, and two $R$. neglectus). Five nymphs captured in the intradomicile in Maringá and Floriano were Tr. sordida.

Serological testing was performed on $4.2 \%$ of the rural population within the study's catchment area. If only the northwest region of the State is considered, i.e. excluding the Municipality of Cândido de Abreu, serology was performed on $6.0 \%$ of the 26,215 inhabitants in the rural area Samples were collected from DU residents present at the time of the visit, and no 
Inhabited and uninhabited domiciliary units (DUs) investigated for triatomines in Paraná State, Brazil, from June 1996 to February 2000.

\begin{tabular}{|c|c|c|c|c|c|c|c|c|}
\hline \multirow[t]{2}{*}{$\begin{array}{l}\text { Municipality or district/ } \\
\text { FUNASA classification }\end{array}$} & \multicolumn{2}{|c|}{$\begin{array}{l}\text { Total existing DUs / } \\
\text { total DUs visited }\end{array}$} & \multicolumn{2}{|c|}{$\begin{array}{l}\text { Total inhabited } \\
\text { DUs visited }\end{array}$} & \multicolumn{2}{|c|}{$\begin{array}{c}\text { Number existing inhabited } \\
\text { houses/ number inhabited } \\
\text { houses visited }\end{array}$} & \multicolumn{2}{|c|}{$\begin{array}{l}\text { Total uninhabited } \\
\text { DUs visited }\end{array}$} \\
\hline & Number & $\%$ & Number & $\%$ & Number & $\%$ & Number & $\%$ \\
\hline Paiçandu /III & $142 / 72$ & 50.7 & 60 & 83.3 & $196 / 83$ & 42.3 & 12 & 16.7 \\
\hline Dr Camargo /III & $235 / 72$ & 30.6 & 70 & 97.2 & 299/89 & 29.8 & 2 & 2.8 \\
\hline Floriano /II & $182 / 60$ & 33.0 & 59 & 98.3 & $272 / 88$ & 32.3 & 1 & 1.7 \\
\hline Floresta /II & $188 / 44$ & 23.4 & 42 & 95.5 & $291 / 65$ & 22.3 & 2 & 4.5 \\
\hline Mandaguari /II & $1,329 / 72$ & 5.4 & 67 & 93.1 & $1,884 / 95$ & 5.0 & 5 & 6.9 \\
\hline Ourizona /II & $183 / 46$ & 25.1 & 30 & 65.2 & $250 / 41$ & 16.4 & 16 & 34.8 \\
\hline Marialva /III & $986 / 47$ & 4.8 & 47 & 100.0 & $1,574 / 75$ & 4.8 & - & - \\
\hline Cândido de Abreu /I & $2,518 / 47$ & 1.9 & 47 & 100.0 & $3,000 / 56$ & 1.9 & 0 & 0.0 \\
\hline Maringá /II & $915 / 59$ & 6.4 & 54 & 91.5 & $1,746 / 103$ & 5.9 & 5 & 8.5 \\
\hline Porto Rico & $211 / 48$ & 22.7 & 33 & 68.8 & $301 / 47$ & 15.6 & 15 & 31.9 \\
\hline Total & $6,889 / 567$ & 8.2 & 509 & 89.8 & $9,813 / 742$ & 7.6 & 58 & 10.2 \\
\hline
\end{tabular}

* On an inhabited DU, more than one inhabited house can exist on the same farm property, FUNASA: Brazilian National Health Foundation.

one refused to cooperate with the procedure. Humans and animals whose blood samples were taken belonged to DUs from localities which were homogeneously distributed throughout the municipality.

Table 3 includes the results for prevalence of $T$. cruzi antibodies, with testing performed on $1,762(61.8 \%)$ humans, $21.0 \%$ of whom were less than 15 years old, all negative. Ten subjects 15 years or older were seropositive for T. cruzi, and they had the results confirmed in the test conducted in serum. These patients were referred to the Health Service for diagnostic confirmation and to the ACHEI Program for psychosocial support 19 . Nine of the ten seropositive individuals were originally from the State of São Paulo, and one was from the State of Minas Gerais. All reported that during their childhood in those States, they had lived in houses infested with barbeiros (the common name for the vector). These subjects reported that while residing in Paraná they did not recall having seen triatomines in their homes. As for prevalence of T. cruzi antibodies in domestic animals, none tested positive (Table 3 ).

Of a total of 1,227 dogs and 979 cats on inhabited rural properties visited during the course of the study, serological testing was performed on 122 (9.9\%) and 49 (5.0\%), respectively (Table 3 ). None of the domestic animals was seropositive for T. cruzi.

According to the logistic model, in the Municipality of Paiçandu there was a significant association $(\mathrm{P}<0.05)$ between presence of triatomines and longer time of residence (16.6 \pm 14.3 years) and distance between the DU and residual wooded areas or "scrub forest" (441.2 $\pm 434.5 \mathrm{~m}$ ). However, only distance between DU and residual wooded areas entailed a significant risk (1.27) of triatomine infestation (the closer the dwelling to woods, the higher the risk). For the other municipalities, the logistical model was not sensitive enough to calculate the risk of infestation, due to the small number of triatomines captured. In the municipalities of Mandaguari, Maringá, and Cândido de Abreu, the existence of inhabited houses was the determining factor for triatomine infestation in the logistic model, reinforced by past infestation of the DU. In the municipalities of Floresta, Marialva, and Ourizona and the Floriano district, triatomine infestation at the time of the study was determined by past infestation of the DU. On the other hand, triatomine infestation in the Dr. Camargo municipality was associated with the variables past DU infestation, presence of an uninhabited DU, and proximity of a "vacant dwelling" annex to the domicile. The number of peridomiciliary annexes $(3.6 \pm 1.5)$ and proximity of DUs to residual "scrub forest" $(275.2 \pm 336.6 \mathrm{~m})$ also helped explain the presence of triatomines in that $\mathrm{mu}-$ nicipality.

DU infestation with triatomines in the $\mathrm{Mu}$ nicipality of Porto Rico was not associated with any of the study variables in the logistic model. 
Prevalence of T. cruzi antibody in humans and domestic animals in rural areas of municipalities in Paraná State, Brazil.

\begin{tabular}{|c|c|c|c|c|c|c|c|c|c|c|c|}
\hline \multirow[t]{2}{*}{$\begin{array}{l}\text { Municipality } \\
\text { or district }\end{array}$} & \multirow[t]{2}{*}{$\begin{array}{l}\text { Total rural } \\
\text { population*/ } \\
\text { population } \\
\text { visited }\end{array}$} & \multirow[t]{2}{*}{$\begin{array}{l}\text { Calculated } \\
\text { sample* } \\
\text { size }^{\star}\end{array}$} & \multicolumn{3}{|c|}{$\begin{array}{l}\text { Number of tests } \\
\text { on humans/number } \\
\text { seropositive }\end{array}$} & \multicolumn{2}{|c|}{$\begin{array}{l}\text { Number of rural } \\
\text { children }<15 \text { years } \\
\text { visited and } \% \text { of } \\
\text { tests performed }\end{array}$} & \multicolumn{2}{|c|}{$\begin{array}{l}\text { No. of tests } \\
\text { performed/ } \\
\text { number } \\
\text { seropositive }\end{array}$} & \multirow[t]{2}{*}{$\begin{array}{l}\text { No. dogs in } \\
\text { households } \\
\text { visited and } \\
\% \text { tested }\end{array}$} & \multirow[t]{2}{*}{$\begin{array}{l}\text { Number } \\
\text { of cats in } \\
\text { households } \\
\text { visited (\%) } \\
\text { tested }\end{array}$} \\
\hline & & & Total & $<15$ years & $\geq 15$ years & Number & $\%$ & Dogs & Cats & & \\
\hline Paiçandu & $784 / 303$ & 136 & $189 / 0$ & $38 / 0$ & $151 / 0$ & 72 & 52.7 & $43 / 0$ & $11 / 0$ & 55 (78.2) & $133(8.3)$ \\
\hline Dr. Camargo & $1,196 / 316$ & 144 & $201 / 5$ & $37 / 0$ & $164 / 5$ & 69 & 53.6 & $15 / 0$ & $2 / 0$ & $112(1.8)$ & $110(1.8)$ \\
\hline Floriano & $1,100 / 335$ & 143 & $232 / 0$ & $65 / 0$ & $167 / 0$ & 101 & 64.4 & $7 / 0$ & $6 / 0$ & $138(5.1)$ & $108(5.6)$ \\
\hline Floresta & $1,165 / 214$ & 144 & $138 / 0$ & $29 / 0$ & $109 / 0$ & 63 & 46.0 & $4 / 0$ & $2 / 0$ & $90(4.4)$ & $61(3.3)$ \\
\hline Mandaguari & $7,536 / 343$ & 160 & $206 / 1$ & $38 / 0$ & $168 / 1$ & 90 & 42.2 & $14 / 0$ & $2 / 0$ & $201(7.0)$ & $150(1.3)$ \\
\hline Ourizona & $1,025 / 151$ & 141 & $124 / 3$ & $25 / 0$ & $99 / 3$ & 38 & 65.8 & $0 / 0$ & $0 / 0$ & $67(0.0)$ & $74(0.0)$ \\
\hline Marialva & $6,298 / 317$ & 160 & $175 / 0$ & $18 / 0$ & $157 / 0$ & 67 & 26.9 & $2 / 0$ & $0 / 0$ & $123(1.6)$ & $60(0.0)$ \\
\hline Cândido Abreu & u $15,257 / 337$ & 162 & $202 / 0$ & $74 / 0$ & $128 / 0$ & 130 & 56.9 & $11 / 0$ & $10 / 0$ & $192(5.7)$ & $111(9.0)$ \\
\hline Maringá & $5,887 / 361$ & 159 & $211 / 0$ & $27 / 0$ & $184 / 0$ & 75 & 36.0 & $14 / 0$ & $10 / 0$ & $189(7.4)$ & $119(8.4)$ \\
\hline Porto Rico & $1,224 / 170$ & 145 & $84 / 1$ & $19 / 0$ & $65 / 1$ & 31 & 61.3 & $12 / 0$ & $6 / 0$ & $60(20.0)$ & $53(10.0)$ \\
\hline Total & $41,472 / 2,847$ & 1,494 & $1,762 / 10$ & $370 / 0$ & $1,392 / 10$ & 736 & 50.3 & $122 / 0$ & $49 / 0$ & $1,227(4.0)$ & $979(5.0)$ \\
\hline
\end{tabular}

*Rural population of the municipalities according to National Census Bureau (IBGE) 1996 census,

**Epi Info version 6.0 - 95\% Confidence Interval.

\section{Discussion}

Under the Chagas Disease Control Program in Brazil, the main vector, Tr. infestans, was controlled in the State of Paraná, as in other States of the country. The program is currently in its entomological surveillance phase, responding to reports of findings of triatomines by the population. The State of Paraná was known for the prevalence of Chagas disease in the past. Institutionally speaking, in the 1990s it could only be described as negligent. In this State there were still seven municipalities, including Cândido de Abreu, included in this study, with a persistent possibility of capturing Tr. infestans 21 . In 2000, the Paraná State Health Secretariat launched a proposal to work in these municipalities to achieve complete elimination of Tr. infestans from the State.

The species Tr. infestans was not found during the course of the current study. Three species of triatomines - Tr. sordida, P. megistus, and $R$. neglectus - were infesting DUs in seven of the nine municipalities investigated, justifying their classification as priority II and III at that time by FUNASA.

Tr. sordida was the most frequent species in the municipalities, particularly in the peridomiciliary setting in Paiçandu, where $36.7 \%$ of the inhabited DUs were infested. It is worth noting that the higher the degree of DU infestation, the greater the possibility of intradomiciliary infestation. However, this pattern is not a rule. In Mambaí, Goiás State, this species was found in more than $10.0 \%$ of DUs, in both the peridomiciliary and intradomiciliary environments 22 . In Porteirinha, Minas Gerais, $34.9 \%$ of DUs were infested with $T r$. sordida, mainly in the peridomiciliary habitat 3 . The State of São Paulo is at present directing its control towards the secondary species Tr. sordida, which is also the prevalent species found in the peridomiciliary environment 23 . According to Forattini et al 24, Chagas disease occurs endemically in Brazil only where there is the possibility of vector domiciliation, and the role of Tr. sordida in T. cruzi transmission is negligible when there are low levels of DU infestation and when colonization is lacking.

A lower proportion of the $P$. megistus species was collected only in the municipalities of Maringá, Mandaguari, Marialva, and Porto Rico, mainly in the intradomicile of inhabited DUs. In the first three municipalities, this work was temporarily suspended due to logistic problems related to FUNASA policies and priorities.

No triatomines were captured in Cândido de Abreu during the course of the present study. Nevertheless, the municipality has been included in the Triatoma infestans Eradiction Program - which classifies municipalities as free of Tr. infestans when they present totally negative DUs for a period of three consecutive years 21 - since this species may still be cap- 
tured in this municipality. On visits made after the collection period of the present study, FUNASA captured P. megistus from DUs in Cândido de Abreu and Paiçandu. According to the literature 4,11 this species has a higher $T$. cruzi vector potential than Tr. sordida.

Based on observation, in the various municipalities Tr. sordida was related to residual forest or "scrub forest" and P. megistus to the "islands of residual forest". These data are consistent with the literature 17,25 .

A large portion (49.1\%) of P. megistus specimens captured were which did not present colonization, although the research was conducted outside this species' dispersion period (Table 1) 24 . For Tr. sordida, adults accounted for only $27.2 \%$ of the specimens captured (mainly in the peridomicile). This provides evidence of colonization by this species.

Although intradomiciliary infestation in the various municipalities occurred by Tr. sordida nymphs or $P$. megistus adults and no positive individuals under 15 years of age were diagnosed, abandonment of the Control Program by normally responsible individuals is of great concern. This is because Tr. sordida colonies were detected in the peridomicile, $P$. megistus displays great T. cruzi transmission potential, and according to Falavigna-Guilherme et al. 12 the $T$. cruzi infection rate for Tr. sordida and $P$. megistus captured in these same municipalities was $13.4 \%$ and $13.5 \%$, respectively, although human blood was only detected rarely as a meal source for these triatomine species. In addition, the chance occurrence of three isolated cases of vector-borne disease in children less than twelve years of age in Paraná in a two-year period must be considered, since they were diagnosed under special conditions 26 .

It is important to note that many DU owners reside in urban settings and frequently transport objects (including timber) from the rural to the urban area and vice versa. In addition, most rural residents do not express concern over the unkempt state of the peridomiciliary environment and many do not appreciate the importance of the presence of triatomines and the problems related to Chagas disease. In addition, some DUs are temporarily uninhabited due to the type of crops grown on the farm property but may receive workers who stay overnight during the harvest season, in proximity with rodents, marsupials, and triatomines originating from nearby "scrub forests".

The factors contributing to the presence of triatomines in the DUs were the same in all nine municipalities. Triatomine presence in
DUs in the Municipality of Paiçandu, according to the logistic model, showed that "proximity of the DU" to "scrub forest" was significant. Furthermore, the longer the "length of residence" in the Municipality of Paiçandu, the higher the possibility that the DU was infested with triatomines. This is in accordance with the characteristics of Paiçandu residents who had lived there the longest and had the habit of storing debris in the peridomicile.

According to the logistic model, the presence of triatomines in DUs in Mandaguari, Maringá, and Cândido de Abreu was closely associated with the "interior of inhabited domiciles". This trend agrees with $P$. megistus habits and environmental features in Mandaguari and Maringá, where intradomiciliary P. megistus-positive DUs were located near "islands of residual forest”. In Cândido de Abreu, the failure to find $P$. megistus may have been related to the low percentage of DUs visited, but it might also have been related to the intensification of FUNASA's work in recent years, contributing to triatomine control in this municipality.

Triatomines were found primarily in the peridomicile in the municipalities of Floresta and Marialva and the Floriano district. Most specimens captured belonged to Tr. sordida. In these municipalities, according to the logistic model, the variable "positive DU in the past" was the only one to predict the presence of triatomines. This situation may be explained by the fact that insecticides applied in annexes are more exposed to sunlight, wind, and rain, which may reduce the duration of efficacy 27 .

Presence of Tr. sordida in the municipality of Dr. Camargo may be explained by the variables "positive DU in the past", "uninhabited DUs”, “empty houses”, “chicken coops”, "pigsties", "number of annexes", and "proximity to scrub forest", either singly or in combination. DU annexes in this municipality were concentrated in a peridomiciliary area of approximately $200 \mathrm{~m}^{2}$, located on average $275 \mathrm{~m}$ from modified woodlands. Diotaiuti et al. 3 reported similar conditions for presence of Tr. sordida in the peridomiciliary environment.

In the Municipality of Porto Rico, the analyzed variables did not statistically explain the presence of DUs infested by P. megistus as compared to R. neglectus. However, this statistical result was expected, since this municipality is not a priority for Chagas disease control. Therefore, such infestations in Porto Rico could be incidental.

This study focused on current triatomine infestation in the rural areas of certain municipalities in the State of Paraná. In order to pre- 
vent such situations in the future, the health authorities responsible for epidemiological surveillance in these municipalities, together with the residents themselves, must be aware of (and informed about) their responsibility in maintaining the commendable control of Chagas disease that has been achieved in Brazil as a whole.

\section{Resumo}

Avaliou-se a infestação por triatomíneos, a prevalência sorológica para T. cruzi em humanos e em animais domésticos, e a pesquisa de variáveis que poderiam estar associadas à presença de triatomíneos na unidade domiciliar (UD) em área rural de nove municípios e um distrito do Paraná, Brasil, junho/1996 a fevereiro/2000. Uma UD foi definida como todas as casas e anexos existentes na propriedade. Amostras de sangue de voluntários humanos, cachorros e gatos foram submetidos à imunoflorescência indireta. Uma ficha epidemiológica foi preenchida para cada UD pesquisada. Foi adotado um modelo logístico para identificar associações. Sete dos nove municípios foram positivos para triatomíneos. T. infestans não foi capturado. T. sordida, P. megistus $e$ R. neglectus foram as espécies capturadas. Diferentes variáveis foram consideradas decisivas para a presença de triatomíneos nos municípios: proximidade à mata residual-capoeira ou ilhas de mata densa, maior tempo de residência, existência de casas habitadas e UD infestada no passado. A fim de assegurar a continuidade do controle da doença de Chagas, medidas de vigilância entomo-epidemiológicas devem ser mantidas nesses municípios.

Triatoma; Variáveis Epidemiológicas; Doença de Chagas

\section{Contributors}

A. L. Falavigna-Guilherme contributed to the elaboration of the research project, literature review, data collection and analysis, and drafting of the final article. R. Santana collaborated in the data analysis. E. S. Lorosa and G. C. Pavanelli participated in the data analysis. S. M. Araújo contributed to the data analysis and revision of the final article.

\section{Acknowledgements}

This study received funding from the post-graduate course in the Ecology of Aquatic and Continental Environments of the Universidade Estadual de Maringá and from the Brazilian National Health Foundation, Brasília (agreement FUNASA/UEM \#1899/98). 


\section{References}

1. Gazin P, Melo G, Albuquerque A, Oliveira JRW. Atualidade da doença de Chagas numa área rural do nordeste do Brasil. França-Flash Cooperação Pesquisa CenDoTeC 1999; 20:1-4.

2. Silva EOR, Wanderley DMV, Rodrigues VLCC. Triatoma infestans: importância, controle e eliminação da espécie no Estado de São Paulo. Rev Soc Bras Med Trop 1998; 31:73-88.

3. Diotaiuti L, Azeredo BV, Busek SCU, Fernandes AJ. Controle do Triatoma sordida no peridomicílio rural do município de Porteirinha, Minas Gerais, Brasil. Rev Panam Salud Pública 1998; 3:21-5.

4. Barreto MP. Epidemiologia. In: Brener Z, Andrade Z, organizadores. Trypanosoma cruzi e doença de Chagas. Rio de Janeiro: Guanabara Koogan; 1979. p. 89-151.

5. Camargo ME, Silva GR, Castilho EA, Silveira AC. Inquérito sorológico da infecção chagásica no Brasil, 1975/1980. Rev Inst Med Trop São Paulo 1984; 26:192-204.

6. Simões AJP. Doença de Chagas no estado do Paraná, Brasil. Esboço epidemiológico. Mem Inst Oswaldo Cruz 1943; 39:279-90.

7. Almeida AS. Doença de Chagas no norte do Paraná. An Paul Med Cir 1948; 56:29-36.

8. Lobo AGS, Borba AM, Souza J. Contribuição ao conhecimento da distribuição geográfica dos triatomíneos domiciliários e seus índices de infecção natural pelo Schizotrypanum cruzi no estado do Paraná. Rev Bras Malariol Doenças Trop 1953; 571-84.

9. Souza-Araújo HC. A doença de Chagas no Paraná. Mem Inst Oswaldo Cruz 1954; 52:477-85.

10. Toledo MJO, Kühl JB, Silva SV, Gasperi MV, Araújo SM. Estudo sobre triatomíneos e reservatórios silvestres de Trypanosoma cruzi no estado do Paraná, sul do Brasil. Resultados preliminares. Rev Soc Bras Med Trop 199; 30:197-203.

11. Silveira AC, Vinhaes M. Doença de Chagas: aspectos epidemiológicos e de controle. Rev Soc Bras Med Trop 1998; 31:15-60.

12. Falavigna-Guilherme AL, Pavanelli GC, Silva SV, Costa AL, Araújo SM. Secondary triatomine species in dwellings and other nearby structures in municipalities under epidemiological surveillance in the State of Paraná, Brazil. Rev Panam Salud Pública 2001; 9:385-92.

13. Instituto Paranaense de Desenvolvimento Econômico e Social. Caderno estatístico municipal: histórico dos municípios. Curitiba: Sistema Estadual de Informações, Base Pública; 1994.

14. Nimer E. Climatologia do Brasil. In: Fundação Instituto Brasileiro de Geografia e Estatística, organizador. Geografia do Brasil - Região Sul. Rio de Janeiro: Fundação Instituto Brasileiro de Geografia e Estatística; 1977. p. 35-79.

15. Instituto Agronômico do Paraná. Cartas climáticas do Estado do Paraná. Londrina: Instituto Agronômico do Paraná; 1994.
16. Alegre M, Moro DA. A mobilidade da população nas antigas áreas cafeeiras do norte do Paraná. Boletim de Geografia 1986; 4:28-73.

17. Forattini OP. Biogeografia, origem e distribuição da domiciliação de triatomíneos no Brasil. Rev Saúde Pública 1980; 14:265-99.

18. Ministério da Saúde, Fundação Nacional de Saúde, Coordenação Regional do Paraná. Programa de controle da doença de Chagas: planejamento de operações de campo para o ano de 1998. Curitiba: Centro de Documentação, Ministério da Saúde; 1997.

19. Araújo SM, Ando MH, Cassarotti DJ, Mota DCGA, Borges SMR, Gomes ML. Programa ACHEI: "Atenção ao Chagásico com Educação Integral no município de Maringá e região noroeste do Paraná”, Brasil. Rev Soc Bras Med Trop 2000; 33:565-72.

20. Collett D. Modeling binary data. New York: Chapman \& Hall; 1994.

21. Secretaria de Estado da Saúde do Paraná. Boletim epidemiológico. Saúde no Paraná. http://www. saude.pr.gov.br/Boletim_Epidemiologico/Primavera_2000/doenca_chagas.htm (acessado em 09/Jun/2000).

22. Marsden P, Garcia-Zapata MTA, Castillo EAS, Pratas AR, Macedo VO. Los 13 primeros años del control de la enfermedad de Chagas em Mambaí, Goiás, Brasil, 1980-1992. Bol Oficina Sanit Panam 1994; 116:111-7.

23. Silva RA, Rodrigues VLC, Carvalho ME, Pauliquévis Jr. C. Programa de controle da doença de Chagas no Estado de São Paulo: persistência de alta infestação por triatomíneos em localidades na década de 1990. Cad Saúde Pública 2003; 19:96571 .

24. Forattini OP, Santos JLF, Ferreira AO, Silva EOR, Rabello EX. Aspectos ecológicos da tripanossomíase americana. XVI - dispersão e ciclos anuais de colônias de Triatoma sordida e de Panstrongylus megistus espontaneamente desenvolvidas em ecótopos artificiais. Rev Saúde Pública 1979; 13:299-313.

25. Silveira AC, Feitosa VR, Borges R. Distribuição de triatomíneos capturados no ambiente domiciliar, no período 1975/83, Brasil. Rev Bras Malariol Doenças Trop 1984; 36:15-312.

26. Araújo SM, Ortiz M, Gomes ML, Costa AL, Membrise $\mathrm{H}$, Toledo MJO, et al. Caso de doença de Chagas em crianças no estado do Paraná. Anais da XVIII Reunião Anual de Pesquisa Aplicada em doença de Chagas Uberaba, MG, Brasil. 17 a 20 de outubro. Uberaba: Sociedade Brasileira de Medicina Tropical; 2002. p. 35.

27. Nascimento C, Marassá AM, Curado I, Piazza RMF. Encontro de Panstrongylus megistus em ecótopo artificial: domiciliação ou mera visitação Rev Soc Bras Med Trop 1997; 30:333-6.

Submitted on $01 /$ Oct $/ 2003$

Final version resubmitted on 10/Nov/2003 Approved on 25/Nov/2003 